International Journal of English Literature and Social Sciences
Vol-6, Issue-2; Mar-Apr, 2021
Journal Home Page Available: https://ijels.com/
Journal DOI: $10.22161 /$ ijels

\title{
The Formations and Policies of Colonial Agriculture in Malabar
}

\author{
Dr. Radhamani.C.P
}

Assistant Professor, Department of History, PRNSS College, Mattannur, Kannur. D.T, India

Received: 03 Feb 2021; Received in revised form: 19 Mar 2021; Accepted: 11 Apr 2021; Available online: 30 Apr 2021

(C)2021 The Author(s). Published by Infogain Publication. This is an open access article under the CC BY license

(https://creativecommons.org/licenses/by/4.0/).

\begin{abstract}
Till the second half of eighteenth-century Malabar was under the rule of Mysore Sulthans and was ceded to the British by the treaty of Seringapattom. During this period the cultivating land was owned by numerous landlords and chieftains in Malabar. The land was leased for cultivation to tenants called kudiyans, kanakudiyans, pattakkaran, verumpattakkaran etc. for cultivation. One of the interesting facts in Malabar was that different persons had rights on a same piece of land based on tradition.The British started revenue assessment and for the collection of taxes the landlords acted as their agents.For this and for the administration of law and order the British established so many law courts and enacted numerous laws.By these laws the traditional land relations were disappeared and the new class of jenmis who had absolute ownership on land came into existence. In the guise of revenue collection excessive levies and charges were imposed on the tenants and these extortions was resulted in to various protests and peasant revolts in different parts of North Malabar. The consequences of colonial policies in agrarian relations in Malabar is examined in this paper.
\end{abstract}

Keywords-Colonial Agriculture, British administrators, laissezfaire principles, Mysorean rulers.

\section{INTRODUCTION}

The British administrators had an ideological affinity towards the seventeenth century English concept of private property, derived from John Locke and others, and it was transmitted to them through the school of Philosophical Radicalism or Utilitarianism. These ideas and laissezfaire principles were decisive forces in controlling the Indian political economy in the nineteenth century. The British land policy under the under the utilitarian principles mainly stood for defining and recording the rights of the landowners and guaranteeing their rights through law courts ${ }^{1}$. The Whig concept of a political society was more concerned on landed property and protection of the rights in the land. Joint control and communal ownership over land were considered as characteristics of a primitive society. As such the existing pattern of agrarian relation among the numerous groups in the rural India were disturbed and disrupted by the English

${ }^{1}$ K.K.N.Kurup, William Logan-A Study in the Agrarian relations of Malabar,Calicut,1981,p.199. administrators in the early stages of colonialism. But the growth of rural population, the integration of the economy and agriculture with the world capitalist system, periodical revision of land tax, absence of scientific cultivation, etc. created an explosive situation in the villages of Malabar especially in grain producing southern Taluks. The social evils arising from the growing dominance of landowners and intermediaries were not so far controlled by the Government. It could not further create conditions favourable for a prosperous agriculture in Malabar owing to defects in the tenurial system, land control and other factors under the colonial government ${ }^{2}$.

By the treaty of Seringapatam in 1792 Tipu Sultan ceded Malabar to the English East India Company and made a part of Bombay Presidency ${ }^{3}$. The Mysorean

2/bid.,p.200.

3 The British Malabar had an area of 5,795 square miles and was divided into nine taluks, namely

Chirakkal,Kottayam,Kurumbranad,Wayanad,Calicut,Ernad,Valluv anaf,Ponnani and Palghat. 
rulers made the settlement with the Kanakkar who were then in possession of land. Taking advantage of this situation the Muslims purchased land at low costs or to seize land withheld by fleeing landlords ${ }^{4}$. But the Kanakkars who became a party to the revenue settlement of Mysorean only tried to preserved their Kanam rights and did not try to seize the Janmam rights.If the Kanakkarregarded the Janmam to be really important right in the soil, they would have definitely claimed this rights ${ }^{5}$. As soon as the British annexed Malabar, they started leasing lands to the Rajas of numerous principalities, whom they had encouraged against the Mysore sultans for lump sums equal to the Mysorean assessment ${ }^{6}$. Naturally the collection of land revenue was done by the deputies of the Rajas .This policy left the country at the mercy of the Rajas who in turn were supported by the might of the British, had pernicious effects. Under this conditions agriculture did not flourish, and that the fields now cultivated (which in some districts bear but a small proportion to those that are waste) should yield but very indifferent crops ${ }^{7}$.

The company's assessment of the tenurial position in the Mysorean period was stated as follows . In the year 1766 Hydar Ali first invaded Malabar the country was divided among a number of petty Rajahs of whom the Zamorin was by far the most powerful . The Village headman were called DeswayJelmway He enjoyed the whole or only a part of the rights which were supposed necessary to the constituting of complete chief of the Desam. These rights together with the landed property of the village were originally obtained from the Nambudiri Brahmins who were the ancient proprietors of the whole country. Another British official wrote in the province of Malabar there was a class of people called Jenmkar or possessors of free hold, for there is not a spot of ground that had not been for one of those claimants, so difference in this from all other countries of India and this is owing to the impossibility of renting".

It could also be seen that the Company's officials of the earlier period were very much anxious to keep the Brahmins satisfied.They were equally anxious to hold to the fled Rajas and Hindus (the lower orders exempted) the

${ }^{4}$ B.A.Prakash,(ed.)Kerala

Economy, Performance,Problems, Perspectives, New

Delhi,1994,p.31.

5 Baden Powell,Land System of British India, Vol.III,New

Delhi,1972,rpt,p.170.

${ }^{6}$ V.V.Kunhikrishnan,Tenancy Legislation in Malabar (1880-

1970),New Delhi,1993.p.91.

7 Murdoch Brown quoted by

S.SrinivasRaghavaiyya,TheMemmorandum on the Progress of

Madrass Presidency during the last 40 years of British

Administration,1983,Appendix,Section 2. prospect of restoring them to the situation they held prior to the Mysorean invasion. One of the officials of the Company stated: "they were then called on to join our standard, as people who in avenging their own injuries might prove useful allies to $\mathrm{us}^{8}$. Further proof to the conciliatory attitude towards Janmis could be seen in Governor-General in council in his reply to the Malabar Joint Commissioner's report. He wrote "whatever importance our possessions on this Malabar coast may in future attain, either in a financial or commercial view, at present their political consequence is most worthy of attention". On account of such factors to the early British administrators accepted the Brahmin tradition that they alone enjoyed the proprietary right in the land ${ }^{9}$

In 1793 a group of Joint Commissioners ${ }^{10}$ were appointed to supervise collection by the Rajas as well as to study the region in order to make more convenient arrangements for revenue collection and general administration. When the Joint Commissioners started their work of enquiring into the land tenures of Malabar the Brahmins and Nairs who had left the region following Mysorean invasion were returning. Farmer, one of the Joint Commissioners to restore them to their estates. They were reinstated with full ownership rights and as per the rule laid down for the restoration they were given the authority to prosecute in law courts for regaining possession which they lost before September $1787^{11}$. This was done in view of the older usurpation of their rights by the Moplah of ErnadTaluk. By 1789 the major part of such possession were reclaimed by landlords except in the Moplah districts. Farmer reported in 1793 that two types of right-holders in land where found in the region. First JelmKars (Janmis) or free holders who hold their lands either by purchase or by hereditary descent. Second Kanam-the Kaars (Kanakkars) or mortgagers, to whom an actual delivery of the land appeared to be made, although the money taken up on it was not at all proportioned to the value of the land Thakery and Warden who was Collector of Malabar for twelve years from 1804 to 1816, also subscribed to the above idea, that the Janmis possessed entire rights on the soil ${ }^{12}$.

\footnotetext{
8 Murdock Brown, Report on Malabar Tenures, $10^{\text {th }}$ April, $9^{\text {th }}$ May 1801,Vol.20915-2550,p.2.

${ }^{9}$ C.A. Innes (ed.),Malabar District Gazetteer,Madras,1951

edn, p.305

${ }^{10}$ The Commission consisted of William GamulFarmer,Major Alexander Dow, William Page and Jonathan Duncon. 11 D,N Dhanagara,Peasant Movement in India 1920-1950, New Delhi,1983,p.60.

${ }^{12} \mathrm{Cf}$.WilliamThackeray, Report on Revenue Affairs of Malabar and Canara,1807,p.212.
} 
The forgoing land settlement infact introduced a new agrarian society thoroughly unknown to pre-British Malabar. The recognition of Janmam as an absolute property right led the Commissioners to declare Kanam as mortgage and Verumpattam as tenancy at will.It was the formal recognition of landlords,as the legal proprietors, which armed them with the right to evict tenants and their authority over tenants could be enforced through British civil courts.It was the political expediency and realization of the potential benefit of a policy of conciliating landed elites to the British authority that stood at the basis of British land policy in Malabar.

One of the far reaching consequences of the tenancy reforms during British period was that they did not draw a bold line between different interests but singled out the substantial tenants for special protection and devoted less attention to other tenants. The twin rights of fixity of tenure and fair rent were granted to tenants who held lands directly from the landlords i.e., the Kanam tenants and every settled cultivators. These reforms raised the Kanam tenants into a new class of landlords who had no interest in agriculture. The interference of the Government helped them enjoying protection from competition. The most important effect of this change was on their tenants, they were exposed to competition and had to become tenants not only of the traditional landlords but also of protected tenants. Their position became worse in the agrarian hierarchy since the migration from other sectors increased the number of people who sought their livelihood in agriculture. On the whole, therefore it must be stated that tenancy reform did not constitute a change in basic economic relationships. This only reshuffled the upper levels of the tenurial hierarchy and exposed the tenants at the bottom, to competition .

The cultivating tenants had no protection of law in regard to fixity of tenure and fair rent. As more people had to be accommodated in the narrow confines of agrarian structure, these unprotected tenants had to pay more rent to retain their holdings. The tenancy legislations afforded little relief to agricultural labourers, the actual tillers of the soil. They were tied to agriculture and it was their main source of livelihood. Their wages depended on the demand of labour and they often received only low wages. They were subjected to both 'old' and 'new' kinds of exploitation. The result of the reform was the multiplication of interest groups in land, which had no inclination whatever to invest directly in agricultural development. The actual cultivators, the last right holder was left high and dry. In consequence, agricultural produce suffered a set-back.
The colonial economy gradually lifted a new stratum to wealth and power, and brought the most ancient and power, and brought the most ancient living aristocracies to an end. The Syrian Christians, Moplahs and Ezhavas as traders and merchants benefited more from cash crop cultivation, commercialization of agriculture, and from the expansion of trade and commerce. They were the people who purchased land from the traditional land owing communities. The mobility of the middle class strengthened the National Congress. The marginal farmers and agricultural labourers under the leadership of the Communist party fought against the evils of landlordism and colonialism. The Party's perpetual struggle helped them to broaden their base in the state, especially in British Malabar.

The land policy of the British in Malabar aimed to achieve two objectives. Firstly, they wanted to extract large share of the agricultural produce as land revenue. Secondly, while achieving this end they were also interested in creating and recognizing a few superior right holders in land who would act as the agents of the British. Thus the application of the British jural norms led to categorization of the agrarian population into Janmis, Kanakkars, Verumpattakkars and agricultural labourers. Thus the erstwhile joint proprietorship or corporate ownership was transformed into individual ownership and the growth of middle peasantry. The restoration of feudal and semi-feudal structures of the through gifts and donations on festive occasions. This practice continued well into the twentieth century on account of the vesting of complete rights over forests and waste lands in the landlord, and the refusal of the government to consider the afflicted question of the rights of tribals over the land they cultivated.

With the expansion of cultivation of cash crops and the development of industries based on agricultural products had accelerated the monetization of economy and wages were paid in cash. Agriculture especially the cultivation of paddy became more extensive in the interior. There was also an increase in the area under paddy cultivation in large extent. Since all waste lands and forests belonged to the Janmis, the peasants had to get permission from the Janmis for cultivation. They had to bear all the responsibility of cultivation and half of the produce was given as rent to the Janmis. The increase in the agricultural population and vast expansion of cash crops created many problems to the tenants.

The fall in the per capita production of paddy and other food crops was one of the striking features of the development of agriculture during this period. At the same time, production of cash crops increased and the growing 
demand for cash crops in world market deflected paddy cultivators, which provided only a small margin of profit.

The development of commercial agriculture involves replacement of subsistence farming by producing crops for trade. While modernization of agriculture implies transformation in the modes and therefore in the relation of production. The shifts in the cropping pattern was chiefly determined by the demand and supply situation, particularly of raw materials. When cultivation became expensive, cultivators took to the practice of borrowing money from local money lenders and landlords. The money lenders and landlords extracted high interest rates from the farmers and absorbed large scale transfer of land from cultivators to non-cultivating, money lending households. As a matter of fact these people had little interest in the modernization of agriculture. Gentleman farmers attracted by the profit and social status resulting from land ownership began to possess land. Their aim was to make more profit not from direct participation in agricultural production but from rack-renting and land speculation.

During this period customary rights disappeared and the labourers became free to sell their labour at prices fixed by the market forces or to remain unemployed, if no work opportunity was available. The new cropping pattern was comparatively less labour absorbing because the perennial cash crop cultivation needed labour only for maintenance and harvesting. That was especially true of women agricultural laboures. The ruin of local manufacturing industries in the colonial period swelled the mass of agricultural labourers and increased the number of people forced to live on land. The agrarian sector could no longer absorb the underutilized and unutilized labour force in the district. The European planters depended mainly on cheap labour available from neighbouring regions outside the district.

The tremendous increase in the population and the decline of traditional manufacturing industries had increased the demand of land for cultivation. During the late 1920s Malabar witnessed the migration of peasants from Travancore because of the high pressure of population on cultivable land in Travancore. The small peasants purchase the lands in Malabar and brought up waste land converted them into paddy fields or orchards and plantation. Increasing capital investment in agricultural sector in highlands of Malabar was the main impact of migration. The migrants introduced crops like tapioca, ginger and lemon grass. As a result of migration rapid changes took place in agriculture and cropping pattern. Cultivation of coffee, rubber, cashew etc. had been rising and the area under food crops fell considerably. The growth of plantations and the expansion of agriculture which was accelerated by the process of migration reduced the area of forests in Malabar. Moreover the migration was also responsible for the fragmentation of agricultural holding in Malabar.

Under the impact of increasing monetization and the advent of capitalism the traditional agricultural system was under strain and stress. Subsistence agriculture was undermined by the introduction of commodity agriculture. The increasing regional specialization and the shift of emphasis from lower to higher value crops diminished not only the income but also changed the attitude of the agriculturists. Food production for local consumption was neglected in favour of articles of food and raw materials for export. Commodity exchanges began to play an important part in the newly evolving economy. Under the new conditions, land was exploited instead of being used for subsistence and crops were produced not for consumption but for sale.

\section{CONCLUSION}

It could be seen that, even if the colonial administration had experimented and introduced different types of cropping patterns, variety of crops, innovative instruments and agricultural practices into Malabar,it had undermined the indigenous agricultural system based on traditional and hereditary relations continued for centuries. They had introduced novel implements, manures and new breeds of plants including cash crops. The value based cultivation has changed into fiscal targeted production. It was the British who transferred subsistence agriculture to market economy based cropping system. The main aim of the British was to create a new class of landlords who are to be designated as their revenue collection agents. Conferring absolute proprietary rights of the land to these new class, replacing the traditional farmers had upsetted the traditional relations as well as the peaceful livelihood of the tenants which in turn has created grevious problems in the law and order of the society. Ultimately it led to open confrontation and peasant uprisings in various parts of Malabar.

\section{REFERENCES}

[1] Dhanagara.D.N,Peasant Movement in India 19201950,New Delhi,1983.

[2] Innes .C.A (ed.),Malabar District Gazetteer,Madras, 1951 edn.

[3] Kunhikrishnan.V.V, Tenancy Legislation in Malabar (1880-1970),New Delhi,1993.

[4] Kurup.K.K.N,William Logan-A Study in the Agrarian Relations of Malabar,Calicut,1981. 
[5] Mathews,Johnsy,Economy and Society in Medieval Malabar (A.D 1500-1600), Changanassery,1996.

[6] Powell,Baden,Land System of British India, Vol.III,New Delhi,1972rpt.

[7] Prakash,B.A (ed,) Kerala Economy, Performance, Problems, Perspectives, New Delhi,1994. 